\title{
Evaluation of the Metabotropic Glutamate Receptor Subtype 5 Using PET and ${ }^{11} \mathrm{C}-\mathrm{ABP} 688$ : Assessment of Methods
}

\author{
Valerie Treyer ${ }^{1}$, Johannes Streffer ${ }^{2}$, Matthias T. Wyss ${ }^{1}$, Andrea Bettio ${ }^{3}$, Simon M. Ametamey ${ }^{3}$, Uta Fischer ${ }^{2}$, \\ Mark Schmidt ${ }^{4}$, Fabrizio Gasparini ${ }^{5}$, Christoph Hock ${ }^{2}$, and Alfred Buck ${ }^{1}$

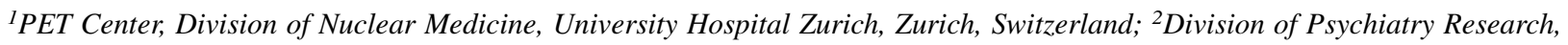 \\ University of Zurich, Zurich, Switzerland; ${ }^{3}$ Center for Radiopharmaceutical Science of ETH, PSI, and USZ, Department of Chemistry \\ and Applied Biosciences of ETH, Zurich, Zurich, Switzerland; ${ }^{4}$ Novartis Pharma AG, Basel, Switzerland; and ${ }^{5}$ Novartis Institutes for \\ Biomedical Research, Basel, Switzerland
}

\begin{abstract}
${ }^{11} \mathrm{C}-\mathrm{ABP} 688$ is a new PET ligand to assess the subtype 5 metabotropic glutamate receptor $\left(\mathrm{mGlu}_{5}\right)$. The purpose of this study was to evaluate different methods for the analysis of human ${ }^{11} \mathrm{C}-\mathrm{ABP} 688$ data acquired from 6 healthy, young volunteers. Methods: The methods were a 1-tissue-compartment model $\left(\mathrm{K}_{1}, \mathrm{k}_{2}{ }^{\prime \prime}\right)$, a 2-tissue-compartment model (K1-k4), and the noncompartmental method developed by Logan. Parameters related to receptor density were the total distribution volume (DV), DV" (= $\mathrm{K}_{1} / \mathrm{k}_{2}{ }^{\prime \prime}, 1$ tissue compartment); specific DV, DV $\mathrm{C} 2_{2}$ (= $\mathrm{K}_{1} / \mathrm{K}_{2}{ }^{\prime} \times \mathrm{K}_{3}{ }^{\prime} / \mathrm{k}_{4}$, 2 tissue compartments); and $D V_{\text {tot }}$ for the noncompartmental method. Results: The 1-tissue-compartment model was too simple to adequately fit the data. $\mathrm{DV}_{\mathrm{C} 2}$ calculated with the 2-tissue-compartment model ranged from $5.45 \pm 1.47$ (anterior cingulate) to $1.91 \pm 0.32$ (cerebellum). The corresponding values for $\mathrm{DV}_{\text {tot }}$, calculated with the 2-tissue-compartment model and the Logan method (in parentheses), were $6.57 \pm$ $1.45(6.35 \pm 1.32)$ and $2.93 \pm 0.53(2.48 \pm 0.40)$. There was no clear evidence of a region devoid of $\mathrm{mGlu}_{5}$ receptors. The first-pass extraction fraction exceeded $95 \%$. The minimal scan duration to obtain stable results was estimated to be $45 \mathrm{~min}$. Conclusion: ${ }^{11} \mathrm{C}-\mathrm{ABP} 688$ displays favorable kinetics for assessing $\mathrm{mGlu}_{5}$ receptors. For tracer kinetic modeling, 2-tissue-compartment models are clearly superior to models with only 1 tissue compartment. In comparison to the compartmental models, the Logan method is equally useful if only $D V_{\text {tot }}$ values are required and fast pixelwise parametric maps are desired. The lack of regions devoid of receptors limits the use of reference region methods that do not require arterial blood sampling. Another advantage of the tracer is the fast kinetics that allow for relatively short acquisitions.
\end{abstract}

Key Words: positron emission tomography; kinetic modeling; molecular imaging; $\mathrm{mGlu}_{5} ;{ }^{11} \mathrm{C}-\mathrm{ABP} 688$

J Nucl Med 2007; 48:1207-1215

DOI: 10.2967/jnumed.107.039578

Received Jan. 4, 2007; revision accepted Mar. 23, 2007.

For correspondence or reprints contact: Alfred Buck, MD, University Hospital Zurich, Division of Nuclear Medicine, Rämistrasse 100, 8091 Zurich, Switzerland.

E-mail: fred.buck@usz.ch

COPYRIGHT (c) 2007 by the Society of Nuclear Medicine, Inc.
A s of today, 8 subtypes of the metabotropic glutamate receptor have been cloned $\left(\mathrm{mGlu}_{1}-\mathrm{mGlu}_{8}\right)$. Based on their amino-acid sequence, pharmacology, and second messenger coupling, these receptors have been classified into 3 groups (I-III) (1). Group I includes $\mathrm{mGlu}_{1}$ and $\mathrm{mGlu}_{5}$ receptors; Group II includes $\mathrm{mGlu}_{2}$ and $\mathrm{mGlu}_{3}$ receptors; and Group III includes $\mathrm{mGlu}_{4}, \mathrm{mGlu}_{6}, \mathrm{mGlu}_{7}$, and $\mathrm{mGlu}_{8}$ receptors. Recent discoveries of small molecules that selectively interact with receptors of Groups I and II have allowed significant advances in the understanding of the roles of these receptors in brain physiology and pathophysiology (2). Based on the wide and consistent effects of selective noncompetitive allosteric antagonists such as MPEP (2-methyl6-(phenylethynyl)pyridine) in animal models for anxiety $(3,4)$, it has been hypothesized that the $\mathrm{mGlu}_{5}$ receptor could be a valuable target for the treatment of anxietyrelated disorders (5-7). Although several $\mathrm{mGlu}_{5}$ receptor antagonists have successfully been used in vitro to label $\mathrm{mGlu}_{5}$ receptors $(8,9)$, the development of these ligands to useful PET tracers has proven difficult. Only recently has a series of PET ligands allowing in vivo imaging in rhesus monkeys been described (10). Lately, we identified another promising ligand: ${ }^{11} \mathrm{C}-\mathrm{ABP} 688$ (3-(6-methyl-pyridin-2ylethynyl)-cyclohex-2-enone- $O-{ }^{11} \mathrm{C}$-methyl-oxime). This compound is a highly selective allosteric antagonist of the $\mathrm{mGlu}_{5}$ receptor in vitro, and initial studies have demonstrated a high selectivity for $\mathrm{mGlu}_{5}$ receptors in vivo $(11,12)$. The major purpose of this study was to evaluate several methods of analyzing human ${ }^{11} \mathrm{C}$-ABP688 data. The chosen methods were compartmental modeling using 1 and 2 tissue compartments and the method developed by Logan et al. (13).

\section{MATERIALS AND METHODS}

\section{Synthesis of ${ }^{11} \mathrm{C}-\mathrm{ABP} 688$}

The synthesis of ${ }^{11} \mathrm{C}-\mathrm{ABP} 688$ has been described in detail elsewhere (12). Briefly, desmethyl ABP688 was reacted with ${ }^{11} \mathrm{C}$-methyl iodide produced from the GE PET trace system at 
$90^{\circ} \mathrm{C}$ for $5 \mathrm{~min}$. The product was purified by semipreparative highperformance liquid chromatography using a reversed-phase column. ${ }^{11} \mathrm{C}-\mathrm{ABP} 688$ for in vivo administration to humans was formulated using $0.15 \mathrm{M}$ phosphate buffer and ethanol. Specific activity ranged from 70 to $95 \mathrm{GBq} / \mu \mathrm{mol}$ at the time of injection. This activity corresponds to $0.71-1.04 \mu \mathrm{g}$ of cold ABP688.

\section{Study Population}

Six healthy male volunteers (mean age, 25 y; range, 21-33 y) were studied. None of the subjects had a history of neurologic disorders. The study was approved by the local ethical committee, and written consent was obtained from each volunteer.

\section{PET}

The PET studies were performed in 3-dimensional mode on a whole-body scanner (Discovery LS, GE Healthcare). This scanner has an axial field of view of $14.6 \mathrm{~cm}$ and a reconstructed in-plane resolution of $7 \mathrm{~mm}$. Before positioning of the volunteers on the scanner, catheters were placed in an antecubital vein for tracer injection and the contralateral radial artery for blood sampling. A 10 -min ${ }^{68} \mathrm{Ge}$ transmission scan was acquired for correction of photon attenuation. Transaxial images of the brain were reconstructed using filtered backprojection $(128 \times 128$ matrix, 35 slices, $2.34 \times 2.34 \times 4.25 \mathrm{~mm}$ voxel size) .

$\mathrm{H}_{2}{ }^{15} \mathrm{O}$ PET. Each ABP688 study was preceded by an evaluation of cerebral perfusion (cerebral blood flow [CBF]) using $\mathrm{H}_{2}{ }^{15} \mathrm{O}$. For this purpose, $400-500 \mathrm{MBq}$ of $\mathrm{H}_{2}{ }^{15} \mathrm{O}$ were injected intravenously using an automatic injection device, which delivers a predefined dose of $\mathrm{H}_{2}{ }^{15} \mathrm{O}$ over $20 \mathrm{~s}$. After arrival of the bolus in the brain, a series of eighteen 10-s scans was initiated. The time course of the arterial radioactivity was continuously assessed in a coincidence counter (GE Healthcare), through which blood from the radial artery was run.

${ }^{11} C$-ABP688 PET. Ten minutes after the $\mathrm{H}_{2}{ }^{15} \mathrm{O}$ measurement, 300-350 MBq of ${ }^{11} \mathrm{C}$-ABP688 was injected as a slow bolus over $2 \mathrm{~min}$, and a series of 20 scans was initiated $(10 \times 60 ; 10 \times 300 \mathrm{~s}$; total study duration, $60 \mathrm{~min}$ ). For determination of the arterial input curve, arterial blood samples were collected every $30 \mathrm{~s}$ for the first 6 min and then at increasing intervals until the end of the study. An aliquot of whole blood and plasma was measured in a $\gamma$-counter. Authentic tracer and labeled metabolites in plasma were separated using Waters Sep-Pak tC18 cartridges. A solution of $200 \mu \mathrm{L}$ of plasma diluted with $2.5 \mathrm{~mL}$ of water was passed through the cartridges and eluted with $5 \mathrm{~mL}$ of water. Previous high-performance liquid chromatography studies had shown that the authentic compound was adsorbed in the cartridge and the metabolites were collected in the eluted fraction.

\section{MRI}

MRI was performed to exclude a cerebral pathologic condition. For each subject, T1-weighted (3-dimensional spoiled gradient echo, $0.86 \times 0.86 \times 1.5 \mathrm{~mm}$ pixel size) and T2-weighted (fast spin echo, $0.43 \times 0.43 \times 5 \mathrm{~mm}$ pixel size) whole-brain images were acquired on a 1.5-T Signa Excite system (GE Healthcare).

\section{Data Analysis}

CBF Measurement. Quantitative parametric maps representing regional $\mathrm{CBF}$ were calculated from the $\mathrm{H}_{2}{ }^{15} \mathrm{O}$ images using the integration method described by Alpert (14). The method yielded maps of $K_{1}$ and $k_{2}$, which represent regional $\mathrm{CBF}$ and regional $\mathrm{CBF} / \mathrm{p}$, respectively ( $\mathrm{p}=$ partition coefficient). The underlying model is depicted in Figure 1.
Models and Parameters for Receptor Density. The investigated methods consisted of standard compartmental modeling and the method described by Logan et al. (13). Tracer kinetic modeling was performed using the models depicted in Figure 1. They contain 1 and 2 tissue compartments. The notation using primes is borrowed from Koeppe et al. (15). The meaning of the parameters is as follows. $\mathrm{C}_{1}$ denotes the concentration of specifically and nonspecifically bound ligand in the 1-tissue-compartment model and denotes the concentration of nonspecifically bound ligand in the 2-tissue-compartment model. $\mathrm{C}_{2}$ denotes the concentration of ligand bound to receptors. $\mathrm{K}_{1}$ describes uptake of tracer across the blood-brain barrier and is related to $\mathrm{CBF}$ and the first-pass extraction fraction $\mathrm{EF}\left(\mathrm{K}_{1}=\mathrm{CBF} \mathrm{EF}\right) . \mathrm{k}_{2}{ }^{\prime \prime}$ and $\mathrm{k}_{2}{ }^{\prime}$ represent backdiffusion from tissue to vascular space in the 1- and 2-tissuecompartment models, respectively. $\mathrm{k}_{3}{ }^{\prime}$ describes the transfer of ligand to the receptor, $\mathrm{k}_{3}{ }^{\prime}=\left(\mathrm{k}_{3} / 1+\mathrm{k}_{5} / \mathrm{k}_{6}\right)=\left(\mathrm{k}_{\mathrm{on}} B \max ^{\prime} / 1+\right.$ $\mathrm{k}_{5} / \mathrm{k}_{6}$ ), where $\mathrm{k}_{5}$ and $\mathrm{k}_{6}$ denote the exchange of ligand between the free and nonspecific compartments in the full 3-tissuecompartment model. The term $\left(1 / 1+\mathrm{k}_{5} / \mathrm{k}_{6}\right)$ is equivalent to the term $\mathrm{f} 2$ used by Mintun et al. (16) and others. $\mathrm{k}_{4}$ is equal to $\mathrm{k}_{\mathrm{off}}$ and represents the dissociation constant. DV" is the total DV of tissue activity calculated with the 1-tissue-compartment model $\left(\mathrm{K}_{1} / \mathrm{k}_{2}{ }^{\prime \prime}\right) . \mathrm{DV}_{\mathrm{C} 1}$ is the $\mathrm{DV}$ of compartment $\mathrm{C}_{1}=\mathrm{K}_{1} / \mathrm{k}_{2}{ }^{\prime} \cdot \mathrm{DV}_{\mathrm{C} 2}$ is the $\mathrm{DV}$ of compartment $\mathrm{C}_{2}=\mathrm{K}_{1} / \mathrm{k}_{2}{ }^{\prime} \mathrm{k}_{3}{ }^{\prime} / \mathrm{k}_{4}$. $\mathrm{DV}$ tot is the total $\mathrm{DV}$ of tissue activity calculated with the 2-tissue-compartment model $\left(\mathrm{DV}_{\mathrm{C} 1}+\mathrm{DV}_{\mathrm{C} 2}=\mathrm{K}_{1} / \mathrm{k}_{2}{ }^{\prime}\left(1+\mathrm{k}_{3}{ }^{\prime} / \mathrm{k}_{4}\right)\right.$.

Tracer exchange between the compartments is described by the following differential equations:

$$
\begin{array}{cc}
\frac{d C_{1}}{d t}=K_{1} C_{p}-\left(k_{2}{ }^{\prime}+k_{3}{ }^{\prime}\right) C_{1}+k_{4} C_{2} & \text { Eq. } 1 \\
\frac{d C_{2}}{d t}=k_{3}{ }^{\prime} C_{1}-k_{4} C_{2} & \text { Eq. } 2 \\
\frac{d C_{t}}{d t}=K_{1} C_{p}-k_{2}{ }^{\prime \prime} C_{t} . & \text { Eq. } 3
\end{array}
$$

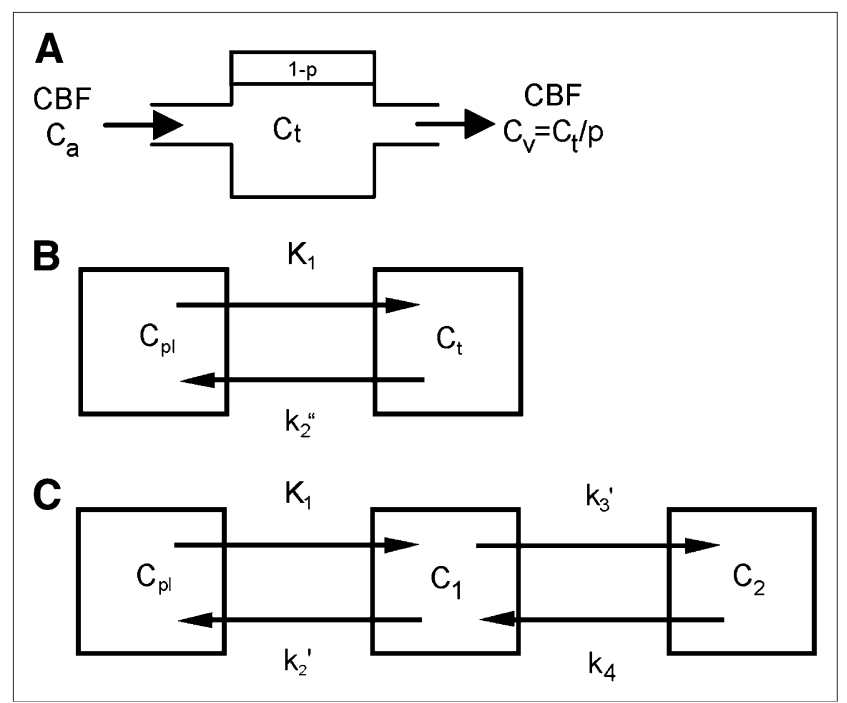

FIGURE 1. One- and 2-tissue-compartment models applied to analyze $\mathrm{CBF}$ using $\mathrm{H}_{2}{ }^{15} \mathrm{O}(\mathrm{A})$ and kinetics of ${ }^{11} \mathrm{C}-\mathrm{ABP} 688$ (B and $\mathrm{C}$ ). 
Equations 1 and 2 describe tracer exchange in the 2-tissuecompartment model; Equation 3, in the 1-tissue-compartment model. Because the total activity measured in a region is composed of counts from tissue and blood, all models contained a parameter $(\alpha)$ correcting for blood activity.

$$
C_{\text {voi }}=(1-\alpha) C t+\alpha C_{b l o o d}
$$

where $\mathrm{C}_{\mathrm{VOI}}$ is the PET counts in a volume of interest, $\alpha$ is the percentage of intravascular space in tissue, $\mathrm{C}_{\text {tot }}$ is the activity in the extravascular compartment (with the 2-tissue-compartment model, $\mathrm{C}_{\text {tot }}$ is the sum of $\mathrm{C}_{1}$ and $\mathrm{C}_{2}$, and $\mathrm{C}_{\text {blood }}$ is the total blood activity). $\mathrm{C}_{\text {tot }}$ was calculated by numeric integration of the differential equations, and $\alpha$ was fixed at 0.05 .

Outcome measures related to the density of $\mathrm{mGlu}_{5}$ receptors are summarized in Table 1. Method A uses the 1-tissue-compartment model, and the only useful outcome measure related to receptor density is the total DV, DV". Methods B-D use the 2-tissuecompartment model and several combinations of parameter coupling. The latter was described in detail previously (17). In short, if one assumes that certain parameters or combinations of parameters are equal among different brain regions, it may be useful to perform simultaneous fitting of all these regions with the constraint of common parameter values. In method $C$, it was assumed that $\mathrm{DV}_{\mathrm{C} 1}$ was equal in all regions; in method $\mathrm{D}, \mathrm{DV}_{\mathrm{C} 1}$ and $\mathrm{k}_{4}$. The coupling encompassed all gray matter regions. With the 2-tissue-compartment model, measures related to receptor density were $\mathrm{DV}_{\text {tot }}$ and $\mathrm{DV}_{\mathrm{C} 2}$.

The Logan plot (13) is a graphical method applicable for analyzing the uptake of reversible receptor tracers. Hereby, the transformed tissue activities $\int_{0}^{t} C_{v o i}\left(t^{\prime}\right) d t^{\prime} / C_{v o i}(t)$ are plotted as a function of the transformed plasma activities $\int_{0}^{t} C_{p}\left(t^{\prime}\right) d t^{\prime} / C_{v o i}(t)$. After some equilibration time, the plotted values approach a linear function and can be described by a regression line. The start time of the linear section in the graphical plot was fitted using an error criterion of $10 \%$ as implemented in the dedicated PMOD software (www.pmod.com). It has been shown that the regression slope represents the total $\mathrm{DV}, \mathrm{DV}_{\text {tot }}$, plus the vascular fraction $\alpha$. Because the Logan method is fast and robust, it is ideally suited for pixelwise analyses.

\section{Volume-of-Interest Analysis}

For the determination of $\mathrm{C}_{\mathrm{voi}}$ in Equation 4, volumes of interest were defined over various structures. For this purpose, the scans were summed and anatomic volumes of interest were defined for each subject individually. The volumes of interest encompassed

TABLE 1

Investigated Methods and Parameters Related to Receptor Density

\begin{tabular}{lcclc}
\hline Method & $\begin{array}{c}\text { No. of } \\
\text { tissue } \\
\text { compartments }\end{array}$ & Model & $\begin{array}{c}\text { Coupled } \\
\text { parameters }\end{array}$ & $\begin{array}{c}\text { Parameters } \\
\text { related to } \\
\text { receptors }\end{array}$ \\
\hline $\mathrm{A}$ & 1 & $\mathrm{~A}$ & None & $\mathrm{DV}^{\prime \prime}$ \\
$\mathrm{B}$ & 2 & $\mathrm{~B}$ & $\mathrm{None}$ & $\mathrm{DV}_{\mathrm{C} 2}$ \\
$\mathrm{C}$ & 2 & $\mathrm{~B}$ & $\mathrm{~K}_{1} / \mathrm{k}_{2}{ }^{\prime}$ & $\mathrm{DV}_{\mathrm{C} 2}$ \\
$\mathrm{D}$ & 2 & $\mathrm{~B}$ & $\mathrm{~K}_{1} / \mathrm{k}_{2}{ }^{\prime}, \mathrm{k}_{4}$ & $\mathrm{DV}_{\mathrm{C} 2}$ \\
\hline
\end{tabular}

4 cortical regions (frontal, parietal, temporal, and occipital), 2 regions within the cingulate gyrus (anterior and posterior), 3 regions in the prosencephalon (caudate, putamen, and thalamus), 3 regions in the limbic systems (medial orbitofrontal cortex, amygdala, and mediotemporal lobe), 1 brain stem region, the cerebellar cortex, and a white matter region.

Tissue time-activity curves were then derived from these volumes of interest. The models were subsequently fitted to these time-activity curves using numeric integration of the operational Equation 4 and Marquart's least-squares algorithm. In addition, parametric maps of $\mathrm{K}_{1}$ and $\mathrm{DV}_{\mathrm{C} 2}$ were calculated using model $\mathrm{B}$, with $\mathrm{DV}_{\mathrm{C} 1}$ fixed to the value obtained from fitting the timeactivity curves using model $\mathrm{C}$. The parametric maps were calculated by voxelwise least-squares fitting. All calculations were performed using PMOD.

\section{Assessment of Methods}

Several criteria were used to assess the different models. Goodness of fit was evaluated using F test statistics, the Akaike information criterion (AIC) (18), and visual inspection of the residuals.

F test:

$$
F=\frac{\left(Q_{A}-Q_{B}\right) /(p B-p A)}{Q_{B} /(n-p B)} .
$$

The AIC is defined as follows:

$$
\begin{aligned}
& A I C A=n \log \left(Q_{A}\right)+2 p A \\
& A I C B=n \log \left(Q_{B}\right)+2 p B .
\end{aligned}
$$

In Equations 5 and 6, $\mathrm{Q}_{\mathrm{A}}$ and $\mathrm{Q}_{\mathrm{B}}$ represent the sum of squares for the fit with models $A$ and $B$, respectively; $p_{A}$ and $p_{B}$ are the number of parameters of models $\mathrm{A}$ and $\mathrm{B}$; and $\mathrm{n}$ is the number of data points. With the $\mathrm{F}$ test, an $\mathrm{F}$ value greater than 3.63 corresponds to a significant improvement using model $\mathrm{B}(P<0.05)$. With AIC, model B is considered to lead to significantly better fits than model A if AIC B is less than AIC A.

The percentage coefficient of variation (COV) across the 6 subjects was chosen as a measure of the stability of the estimated parameters: $\% \mathrm{COV}=\mathrm{SD} /$ mean $\times 100$. Another measure was the $\mathrm{COV}$ derived from the covariance matrix calculated with the Marquardt-Levenberg algorithm.

The effect of study duration on parameter stability was estimated by consecutively shortening the fitting interval in a simulation study from 90 to $5 \mathrm{~min}$. For this purpose, time-activity curves representing a region with a high receptor density (anterior cingulate) were generated using a typical arterial input function and model B. For each study duration, 1,000 curves were generated, and each COV calculated from these parameter sets was taken as a measure of parameter stability.

An alternative to bolus injection is a protocol using a bolus plus a constant infusion. The advantage is that complete equilibrium may be achieved between the tracer concentrations in all relevant compartments. The ratio of tracer in tissue to tracer in plasma then directly reflects $\mathrm{DV}_{\text {tot }}$. On the basis of the kinetic parameters determined in this study, a simulation was performed to estimate the time point at which equilibrium would be achieved with a "bolus plus constant infusion" protocol. The bolus fraction relative to the infusion rate was calculated as described by Carson et al. (19). 


\section{RESULTS}

\section{Time Course in Arterial Plasma}

The time course of total ${ }^{11} \mathrm{C}$ activity in arterial plasma demonstrated the typical shape, with a peak at 30-60 s, which was followed by a rapid decline. The fraction of authentic ${ }^{11} \mathrm{C}$-ABP688 dropped to $64 \%, 44 \%, 35 \%, 28 \%$, $26 \%$, and $25 \%$ at $5,10,15,30,45$, and $60 \mathrm{~min}$, respectively.

\section{One Versus 2 Tissue Compartments}

Examples of tissue time-activity curves of the mediotemporal lobe (high receptor density) and cerebellum (low receptor density) are displayed in Figure 2. Already, the residuals reveal a bias in the fit with the 1-tissue-compartment model, indicating that this model is not sufficient to fit the data. This bias is confirmed by the data presented in Table 2. Adding a second tissue compartment significantly reduced the residual sum of squares in almost all subjects and all regions ( $F$ test). An exception was white matter, for which the 2-tissue-compartment model was unstable. Introducing restrictions such as parameter coupling within the 2-tissue-compartment model did not significantly worsen the fits. The superiority of the 2-tissue-compartment model is furthermore demonstrated by the decline of the AIC and the underestimation of the total DV using the 1-tissuecompartment model (Table 2).

\section{Comparison of Variously Derived DVs}

The results are summarized in Table 3. With all 2-tissuecompartment models, the highest $\mathrm{DV}_{\mathrm{C} 2}$ was found in the anterior cingulate. The coupling of parameters yielded a markedly lower \%COV of $\mathrm{DV}_{\mathrm{C} 2}$ in most regions, an effect that was most pronounced in the areas with high receptor density. The lowest \% COV of $\mathrm{DV}_{\mathrm{C} 2}$ was achieved using model $\mathrm{D}$, in which $\mathrm{DV}_{\mathrm{C} 1}$ and $\mathrm{k}_{4}$ were coupled. In contrast, the effect of parameter coupling on the \%COV of $\mathrm{DV}_{\text {tot }}$ was less pronounced. The same result was obtained by comparing the $\% \mathrm{COV}$ calculated from the covariance matrix. In the anterior cingulate, $\% \mathrm{COV}$ for $\mathrm{DV}_{\mathrm{C} 2}$ was $9.5 \%$ for model $\mathrm{B}$ and dropped to $8.2 \%$ and $4.6 \%$ for models $\mathrm{C}$ and $\mathrm{D}$, respectively (median value of all 6 subjects).

There was excellent agreement between $\mathrm{DV}_{\text {tot }}$ values calculated with the 2-tissue-compartment model and the Logan method.

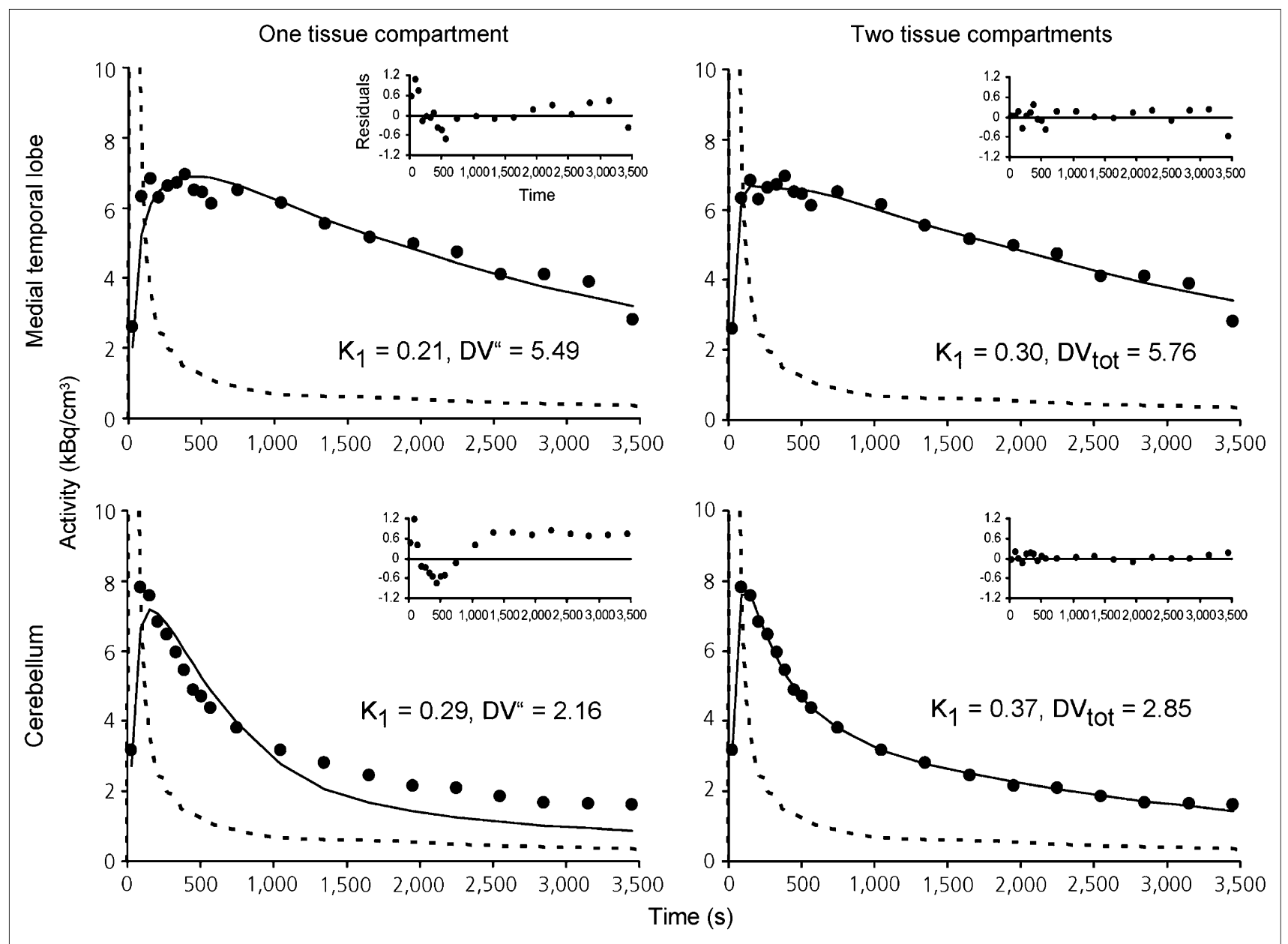

FIGURE 2. Tissue time-activity curves (0), authentic tracer in arterial plasma (dashed line), model fit (solid line), and residuals. Top panels represent region with high receptor density; bottom panels represent region with low receptor density. 
TABLE 2

Model Evaluation

\begin{tabular}{|c|c|c|c|c|c|c|c|c|}
\hline \multirow[b]{3}{*}{ Region } & \multicolumn{6}{|c|}{$\begin{array}{l}\text { No. of subjects (out of 6) with significant reduction/ } \\
\text { increase of sum of squares from model }\end{array}$} & \multirow{2}{*}{\multicolumn{2}{|c|}{$\begin{array}{l}\text { Reduction of } \mathrm{AIC} \text { from } \\
\text { model (A to } \mathrm{B})\end{array}$}} \\
\hline & \multicolumn{2}{|c|}{$A$ to $B$} & \multicolumn{2}{|c|}{$\mathrm{C}$ to $\mathrm{B}$} & \multicolumn{2}{|c|}{$\mathrm{D}$ to $\mathrm{B}$} & & \\
\hline & $\mathrm{B}<\mathrm{A}$ & $B>A$ & $\mathrm{~B}<\mathrm{C}$ & $B>C$ & $\mathrm{~B}<\mathrm{D}$ & $B>D$ & Mean & SD \\
\hline Anterior cingulate & 6 & 0 & 0 & 1 & 0 & 4 & 35.8 & 11.8 \\
\hline Caudate & 6 & 0 & 0 & 0 & 0 & 0 & 17.4 & 10 \\
\hline Medial orbitofrontal cortex & 5 & 0 & 0 & 3 & 0 & 2 & 33.4 & 19.2 \\
\hline Putamen & 6 & 0 & 0 & 3 & 0 & 2 & 32.4 & 9.7 \\
\hline Amygdala & 5 & 0 & 0 & 0 & 0 & 0 & 13.8 & 14.2 \\
\hline Mediotemporal & 6 & 0 & 0 & 1 & 0 & 2 & 16.2 & 10.9 \\
\hline Posterior cingulate & 6 & 0 & 0 & 1 & 0 & 0 & 39.8 & 13 \\
\hline Lateral temporal cortex & 6 & 0 & 0 & 3 & 0 & 2 & 43.1 & 15 \\
\hline Frontal cortex & 6 & 0 & 0 & 3 & 0 & 3 & 52.4 & 19.6 \\
\hline Occipital cortex & 6 & 0 & 0 & 1 & 0 & 2 & 56.2 & 18.9 \\
\hline Thalamus & 6 & 0 & 0 & 0 & 0 & 0 & 27.3 & 11.3 \\
\hline Parietal cortex & 6 & 0 & 0 & 3 & 0 & 2 & 49.3 & 17.3 \\
\hline Brain stem & 6 & 0 & 0 & 0 & 0 & 4 & 17.4 & 7.8 \\
\hline Cerebellum & 6 & 0 & 2 & 0 & 0 & 2 & 51.7 & 18.6 \\
\hline
\end{tabular}

\section{CBF, K1, k3', k4, and First-Pass EF}

The data on $\mathrm{CBF}, \mathrm{K} 1, \mathrm{k} 3^{\prime}, \mathrm{k} 4$, and first-pass $\mathrm{EF}$ are shown in Table $4 . \mathrm{K}_{1}$ values calculated with the 1-tissuecompartment model A are markedly (up to 50\%) lower than those derived from the 2-tissue-compartment models. Parameter coupling generally led to lower \%COVs of $\mathrm{K}_{1}, \mathrm{k}_{3}{ }^{\prime}$, and $\mathrm{k}_{4}$ in most regions; however, there were quite a few exceptions. The largest effect of parameter coupling was

TABLE 3

DVs Calculated with Compartmental Modeling and Logan Method

\begin{tabular}{|c|c|c|c|c|c|c|c|c|c|}
\hline \multirow[b]{2}{*}{ Region } & \multirow[b]{2}{*}{ Parameter } & \multirow{2}{*}{$\begin{array}{c}\mathrm{DV}^{\prime \prime} \\
\mathrm{A}\end{array}$} & \multicolumn{3}{|c|}{$\mathrm{DV}_{\mathrm{C} 2}$} & \multicolumn{3}{|c|}{$\mathrm{DV}_{\text {tot }}$} & \multirow[b]{2}{*}{$\mathrm{DV}_{\text {log }}$} \\
\hline & & & $\mathrm{B}$ & $\mathrm{C}$ & $\mathrm{D}$ & $\mathrm{B}$ & $\mathrm{C}$ & $\mathrm{D}$ & \\
\hline \multirow[t]{2}{*}{ Anterior cingulate } & Mean & 6.07 & 5.45 & 5.48 & 5.28 & 6.57 & 6.62 & 6.40 & 6.35 \\
\hline & $\% \mathrm{COV}$ & 23.1 & 26.9 & 25.0 & 24.3 & 22.1 & 22.2 & 23.2 & 20.9 \\
\hline \multirow[t]{2}{*}{ Caudate } & Mean & 5.82 & 5.04 & 5.13 & 5.12 & 6.31 & 6.27 & 6.25 & 6.05 \\
\hline & $\% \mathrm{COV}$ & 22.2 & 26.2 & 24.6 & 22.8 & 21.3 & 21.6 & 21.1 & 19.2 \\
\hline \multirow[t]{2}{*}{ Medial orbitofrontal cortex } & Mean & 5.82 & 5.08 & 5.07 & 5.05 & 6.21 & 6.21 & 6.17 & 6.02 \\
\hline & $\% \mathrm{COV}$ & 24.4 & 30.0 & 27.4 & 25.8 & 23.9 & 23.9 & 23.7 & 24.4 \\
\hline \multirow[t]{2}{*}{ Putamen } & Mean & 5.53 & 4.60 & 4.93 & 4.89 & 6.19 & 6.07 & 6.01 & 5.96 \\
\hline & $\% \mathrm{COV}$ & 24.7 & 25.2 & 25.5 & 23.7 & 23.4 & 23.1 & 22.3 & 21.5 \\
\hline \multirow[t]{2}{*}{ Amygdala } & Mean & 5.59 & 4.77 & 4.83 & 4.77 & 5.97 & 5.97 & 5.89 & 5.73 \\
\hline & $\% \mathrm{COV}$ & 23.8 & 32.1 & 28.5 & 25.8 & 24.2 & 24.5 & 23.5 & 25.3 \\
\hline \multirow[t]{2}{*}{ Mediotemporal } & Mean & 5.55 & 4.59 & 4.73 & 4.77 & 5.91 & 5.87 & 5.89 & 5.64 \\
\hline & $\% \mathrm{COV}$ & 21.7 & 27.6 & 25.4 & 22.0 & 22.1 & 22.6 & 21.1 & 22.7 \\
\hline \multirow[t]{2}{*}{ Posterior cingulate } & Mean & 5.23 & 4.49 & 4.59 & 4.53 & 5.74 & 5.73 & 5.65 & 5.52 \\
\hline & $\% \mathrm{COV}$ & 25.5 & 25.6 & 26.1 & 26.4 & 24.2 & 23.2 & 23.9 & 23.2 \\
\hline \multirow{2}{*}{ Lateral temporal cortex } & Mean & 5.18 & 4.33 & 4.40 & 4.40 & 5.55 & 5.54 & 5.53 & 5.33 \\
\hline & $\% \mathrm{COV}$ & 21.6 & 26.4 & 25.1 & 23.3 & 21.9 & 21.8 & 21.3 & 22.0 \\
\hline \multirow[t]{2}{*}{ Frontal cortex } & Mean & 4.98 & 4.32 & 4.26 & 4.23 & 5.39 & 5.40 & 5.35 & 5.18 \\
\hline & $\% \mathrm{COV}$ & 22.1 & 24.2 & 24.0 & 23.6 & 21.0 & 20.9 & 21.4 & 21.1 \\
\hline \multirow[t]{2}{*}{ Occipital cortex } & Mean & 4.56 & 3.91 & 3.91 & 3.85 & 5.04 & 5.05 & 4.98 & 4.88 \\
\hline & $\% \mathrm{COV}$ & 22.7 & 21.7 & 22.7 & 23.3 & 20.7 & 20.3 & 21.7 & 21.7 \\
\hline \multirow[t]{2}{*}{ Thalamus } & Mean & 4.33 & 3.45 & 3.72 & 3.82 & 4.93 & 4.86 & 4.94 & 4.75 \\
\hline & $\% \mathrm{COV}$ & 22.3 & 27.1 & 24.1 & 23.0 & 20.8 & 20.7 & 20.8 & 21.7 \\
\hline \multirow[t]{2}{*}{ Parietal cortex } & Mean & 4.55 & 3.84 & 3.81 & 3.76 & 4.92 & 4.95 & 4.89 & 4.75 \\
\hline & $\% \mathrm{COV}$ & 21.5 & 23.0 & 23.3 & 23.5 & 20.6 & 20.5 & 21.3 & 20.5 \\
\hline \multirow[t]{2}{*}{ Brain stem } & Mean & 2.79 & 1.87 & 1.98 & 2.29 & 3.14 & 3.12 & 3.41 & 2.97 \\
\hline & $\% \mathrm{COV}$ & 24.8 & 30.7 & 30.7 & 30.6 & 22.0 & 22.0 & 23.1 & 22.3 \\
\hline \multirow[t]{2}{*}{ Cerebellum } & Mean & 2.24 & 1.91 & 1.86 & 1.73 & 2.93 & 3.00 & 2.86 & 2.48 \\
\hline & $\% \mathrm{COV}$ & 16.4 & 16.7 & 22.5 & 32.0 & 18.1 & 16.2 & 19.7 & 16.2 \\
\hline \multirow[t]{2}{*}{ White matter } & Mean & 2.62 & Unstable fits & & & Unstable fits & & & 2.45 \\
\hline & $\% \mathrm{COV}$ & 21.6 & & & & & & & 23.0 \\
\hline
\end{tabular}


TABLE 4

CBF and Kinetic Rate Constants

\begin{tabular}{|c|c|c|c|c|c|c|c|c|c|c|c|c|c|c|}
\hline \multirow[b]{2}{*}{ Region } & \multirow[b]{2}{*}{ Parameter } & \multirow[b]{2}{*}{ CBF } & \multicolumn{4}{|c|}{$\mathrm{K}_{1}$} & \multicolumn{3}{|c|}{$\mathrm{DV}_{\mathrm{C} 1}\left(=\mathrm{K}_{1} / \mathrm{k}_{2}{ }^{\prime}\right)$} & \multicolumn{3}{|c|}{$\mathrm{k}_{3}^{\prime}$} & \multicolumn{2}{|l|}{$\mathrm{k}_{4}$} \\
\hline & & & A & B & C & $\mathrm{D}$ & $\mathrm{B}$ & C & $\mathrm{D}$ & $\mathrm{B}$ & $\mathrm{C}$ & $\mathrm{D}$ & B & C \\
\hline \multirow[t]{2}{*}{ Anterior cingulate } & Mean & 0.65 & 0.30 & 0.61 & 0.59 & 0.54 & 1.12 & 1.14 & 1.12 & 0.35 & 0.32 & 0.39 & 0.07 & 0.07 \\
\hline & $\% \mathrm{COV}$ & 17.8 & 14.9 & 31.7 & 31.6 & 29.8 & 47.4 & 27.9 & 30.2 & 25.7 & 11.4 & 19.6 & 32.1 & 36.5 \\
\hline \multirow[t]{2}{*}{ Caudate } & Mean & 0.64 & 0.33 & 0.64 & 0.64 & 0.63 & 1.27 & 1.14 & 1.12 & 0.36 & 0.38 & 0.39 & 0.08 & 0.09 \\
\hline & $\% \mathrm{COV}$ & 20.4 & 12.1 & 29.3 & 30.5 & 27.1 & 46.6 & 26.6 & 28.8 & 54.1 & 17.7 & 22.0 & 24.4 & 30.6 \\
\hline \multirow{2}{*}{$\begin{array}{l}\text { Medial orbitofrontal } \\
\text { cortex }\end{array}$} & Mean & 0.59 & 0.29 & 0.54 & 0.50 & 0.50 & 1.13 & 1.14 & 1.12 & 0.41 & 0.37 & 0.38 & 0.09 & 0.09 \\
\hline & $\% \mathrm{COV}$ & 20.9 & 11.4 & 38.9 & 27.8 & 23.0 & 50.0 & 27.9 & 30.2 & 35.5 & 15.1 & 22.2 & 45.4 & 40.9 \\
\hline \multirow[t]{2}{*}{ Putamen } & Mean & 0.61 & 0.35 & 0.62 & 0.71 & 0.71 & 1.60 & 1.14 & 1.12 & 0.22 & 0.34 & 0.37 & 0.07 & 0.08 \\
\hline & \%COV & 18.1 & 10.3 & 24.9 & 25.7 & 24.3 & 28.3 & 26.6 & 28.8 & 41.5 & 15.0 & 19.8 & 21.1 & 20.3 \\
\hline \multirow[t]{2}{*}{ Amygdala } & Mean & 0.44 & 0.24 & 0.40 & 0.38 & 0.37 & 1.20 & 1.14 & 1.12 & 0.35 & 0.37 & 0.36 & 0.08 & 0.10 \\
\hline & $\% \mathrm{COV}$ & 12.5 & 13.5 & 26.6 & 27.9 & 22.7 & 55.1 & 26.6 & 28.8 & 41.1 & 32.6 & 20.1 & 48.0 & 71.4 \\
\hline \multirow[t]{2}{*}{ Mediotemporal } & Mean & 0.46 & 0.25 & 0.41 & 0.38 & 0.39 & 1.32 & 1.14 & 1.12 & 0.37 & 0.42 & 0.36 & 0.09 & 0.11 \\
\hline & $\% \mathrm{COV}$ & 22.0 & 7.1 & 34.6 & 20.7 & 13.9 & 49.7 & 26.6 & 28.8 & 49.6 & 39.3 & 20.4 & 50.1 & 66.1 \\
\hline \multirow[t]{2}{*}{ Posterior cingulate } & Mean & 0.67 & 0.33 & 0.66 & 0.67 & 0.66 & 1.24 & 1.14 & 1.12 & 0.31 & 0.32 & 0.34 & 0.08 & 0.08 \\
\hline & $\% \mathrm{COV}$ & 17.9 & 13.7 & 30.6 & 36.2 & 35.1 & 49.2 & 27.9 & 30.2 & 35.0 & 17.4 & 26.3 & 17.2 & 18.3 \\
\hline \multirow{2}{*}{$\begin{array}{l}\text { Lateral temporal } \\
\text { cortex }\end{array}$} & Mean & 0.47 & 0.27 & 0.47 & 0.44 & 0.44 & 1.22 & 1.14 & 1.12 & 0.35 & 0.32 & 0.33 & 0.08 & 0.08 \\
\hline & $\% \mathrm{COV}$ & 17.4 & 10.9 & 29.1 & 24.2 & 20.4 & 58.1 & 26.6 & 28.8 & 49.9 & 16.4 & 23.9 & 20.5 & 26.8 \\
\hline \multirow[t]{2}{*}{ Frontal cortex } & Mean & 0.58 & 0.29 & 0.57 & 0.52 & 0.52 & 1.07 & 1.14 & 1.12 & 0.35 & 0.30 & 0.32 & 0.08 & 0.08 \\
\hline & $\% \mathrm{COV}$ & 22.3 & 10.7 & 30.9 & 26.8 & 26.0 & 47.7 & 26.6 & 28.8 & 37.6 & 15.0 & 23.5 & 15.7 & 18.2 \\
\hline \multirow[t]{2}{*}{ Occipital cortex } & Mean & 0.58 & 0.29 & 0.60 & 0.57 & 0.56 & 1.13 & 1.14 & 1.12 & 0.30 & 0.26 & 0.29 & 0.08 & 0.08 \\
\hline & $\% \mathrm{COV}$ & 16.6 & 13.2 & 25.2 & 26.3 & 23.8 & 44.5 & 27.9 & 30.2 & 41.9 & 15.2 & 25.3 & 14.5 & 17.7 \\
\hline \multirow[t]{2}{*}{ Thalamus } & Mean & 0.68 & 0.35 & 0.63 & 0.69 & 0.72 & 1.49 & 1.14 & 1.12 & 0.20 & 0.30 & 0.29 & 0.08 & 0.09 \\
\hline & $\% \mathrm{COV}$ & 14.2 & 16.6 & 27.6 & 28.5 & 28.2 & 36.5 & 26.6 & 28.8 & 36.4 & 19.1 & 23.6 & 21.4 & 32.3 \\
\hline \multirow[t]{2}{*}{ Parietal cortex } & Mean & 0.53 & 0.26 & 0.48 & 0.45 & 0.44 & 1.08 & 1.14 & 1.12 & 0.30 & 0.26 & 0.29 & 0.08 & 0.08 \\
\hline & \%COV & 21.4 & 10.5 & 28.0 & 24.4 & 24.0 & 44.2 & 26.6 & 28.8 & 28.7 & 19.4 & 25.6 & 16.6 & 16.5 \\
\hline \multirow[t]{2}{*}{ Brain stem } & Mean & 0.46 & 0.30 & 0.44 & 0.46 & 0.50 & 1.27 & 1.14 & 1.12 & 0.18 & 0.22 & 0.17 & 0.11 & 0.13 \\
\hline & $\% \mathrm{COV}$ & 16.9 & 14.4 & 20.5 & 24.2 & 26.1 & 29.8 & 27.9 & 30.2 & 36.1 & 32.6 & 27.6 & 18.2 & 19.6 \\
\hline \multirow[t]{2}{*}{ Cerebellum } & Mean & 0.51 & 0.32 & 0.54 & 0.55 & 0.54 & 1.02 & 1.14 & 1.12 & 0.15 & 0.11 & 0.13 & 0.08 & 0.06 \\
\hline & $\%$ COV & 11.2 & 20.8 & 18.4 & 30.6 & 30.6 & 21.5 & 27.9 & 30.2 & 29.9 & 42.3 & 42.5 & 30.7 & 24.8 \\
\hline \multirow[t]{2}{*}{ White matter } & Mean & 0.29 & 0.13 & $\begin{array}{l}\text { Unstable } \\
\text { fits }\end{array}$ & & & 1.34 & 1.34 & 1.34 & $\begin{array}{l}\text { Unstable } \\
\text { fits }\end{array}$ & & & $\begin{array}{l}\text { Unstable } \\
\text { fits }\end{array}$ & \\
\hline & $\% \mathrm{COV}$ & 20.3 & 11.9 & & & & 60.1 & 60.1 & 60.1 & & & & & \\
\hline
\end{tabular}

observed on the $\% \mathrm{COV}$ of $\mathrm{k}_{3}{ }^{\prime}$. The $\% \mathrm{COV}$ calculated from the covariance matrix revealed a similar result. In the anterior cingulate, the \% $\mathrm{COV}$ of $\mathrm{k}^{\prime}$ ' dropped from $9.7 \%$ with model B to $8.2 \%$ and $4.0 \%$ with models $C$ and D, respectively (median value of all subjects).

The data listed in Table 4 allow estimation of the firstpass $\mathrm{EF}$. Use of the equation $\mathrm{EF}=\mathrm{K}_{1} / \mathrm{CBF}$ yields a value for $\mathrm{EF}$ of $0.96 \pm 0.05$ (model $\mathrm{B}$, mean among all regions and subjects).

The close correlation of $\mathrm{K}_{1}$ and $\mathrm{CBF}$ is furthermore demonstrated in the left panel of Figure 3. This panel also demonstrates the severe underestimation of $\mathrm{K}_{1}$ using the 1-tissue-compartment model. On the other hand, no correlation was found between $\mathrm{DV}_{\text {tot }}$ (or $\mathrm{DV}_{\mathrm{C} 2}$, data not shown) and $\mathrm{CBF}$ (right panel of Fig. 3).

Parametric maps of $\mathrm{CBF}, \mathrm{K}_{1}$, and $\mathrm{DV}_{\mathrm{C} 2}$ together with the MRI scans are demonstrated in Figure 4. Image quality was high. The similarity in the patterns of $\mathrm{K}_{1}$ and CBF is obvious, as is the difference from the pattern of $\mathrm{DV}_{\mathrm{C} 2}$.

\section{Effect of Study Duration on Parameter Stability}

The results of the simulation study are presented in Figure 5. The least effect of shortening the scan duration was found for $\mathrm{K}_{1}$. With a scan duration of 5 min, stable $\mathrm{K}_{1}$ values could already be calculated. Longer scan durations were needed to obtain stable results for DV values. A steep increase in $\% \mathrm{COV}$ is seen for $\mathrm{DV}_{\text {tot }}$ and $\mathrm{DV}_{\mathrm{C} 2}$ for scan durations of less than $45 \mathrm{~min}$, at which time \%COV was on the order of $12.4 \%$ and $10.5 \%$. This value dropped to under $10 \%$ with 60 min of data. The actual values of $\mathrm{DV}_{\mathrm{C} 2}$ and $\mathrm{DV}_{\text {tot }}$ were markedly underestimated with scan durations of less than $20 \mathrm{~min}$. With scan durations of longer than 20 min, the bias dropped to under $3 \%$.

\section{"Bolus Plus Constant Infusion" Protocol}

In the "bolus plus constant infusion" protocol, the optimal bolus fraction was dependent on the region. A bolus fraction of 53 times the infusion rate per minute was considered a suitable compromise. This value was the mean of the optimal fraction determined for the anterior cingulate (high receptor region) and cerebellum (low receptor region). The simulated time course of the ratio $\mathrm{C}_{\text {tissue }} / \mathrm{C}_{\text {plasma }}$ is demonstrated in Figure 6 for the anterior cingulate and cerebellum. At $30 \mathrm{~min}$, the ratio in the anterior cingulate and cerebellum reached $98 \%$ and $108 \%$, respectively, of the equilibrium value. The corresponding values were $99 \%$ 


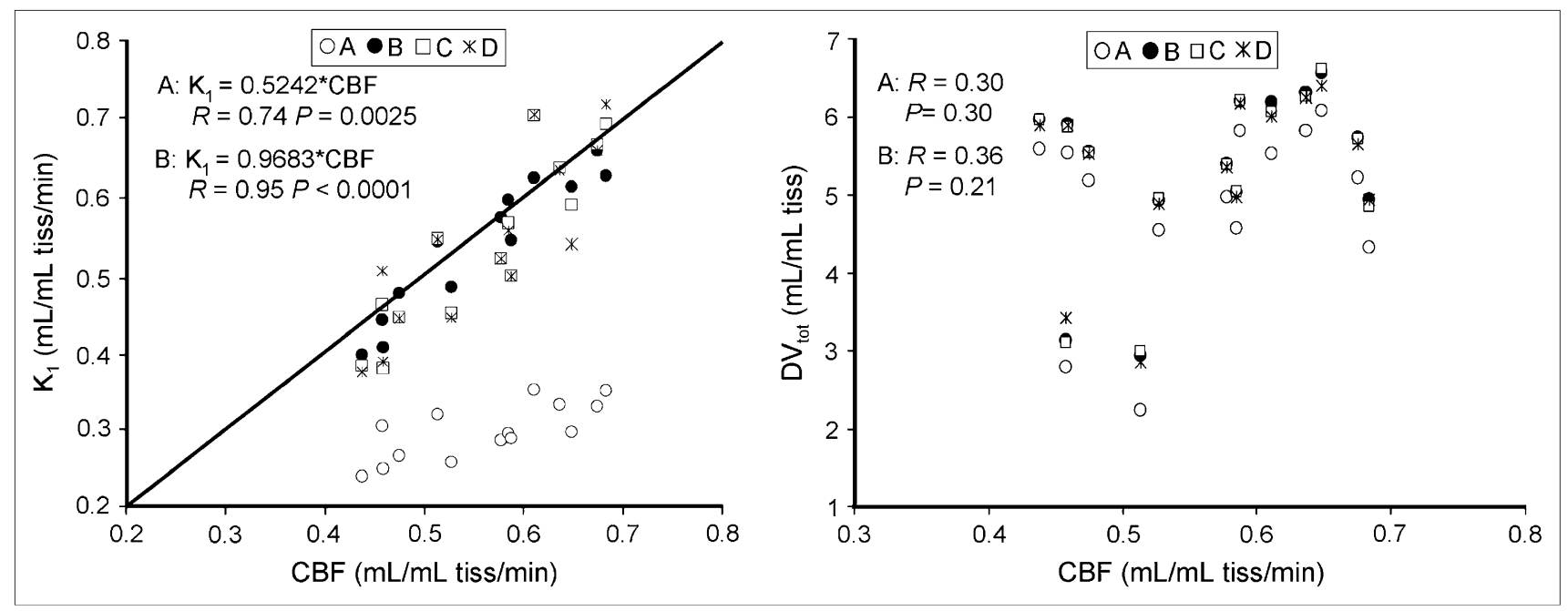

FIGURE 3. Left panel demonstrates correlation of $\mathrm{K}_{1}$ calculated with 2-tissue-compartment models $\mathrm{B}, \mathrm{C}$, and $\mathrm{D}$ (Table 1 ) and CBF. Open circles represent values calculated with 1-tissue-compartment model. Data points represent analyzed regions (mean among all subjects). Right panel depicts same for $\mathrm{DV}_{\text {tot }}$.

and $103 \%$ at 40 min, finally reaching $100 \%$ and $99.9 \%$ at $60 \mathrm{~min}$.

\section{DISCUSSION}

\section{Tissue Compartment Models and the Logan Method}

This study clearly demonstrated that a 2-tissue-compartment model is superior to a 1-tissue-compartment model for analyzing ${ }^{11} \mathrm{C}$-ABP688 data. With the latter, the fits in basically all regions were biased and $\mathrm{K}_{1}$ and the total DV were underestimated. One advantage of the 2-tissuecompartment model is that specific and nonspecific binding can potentially be separated. In the present study, $\mathrm{DV}_{\mathrm{C} 2}$ in the putamen was $74 \%$ of total DV. A disadvantage of the 2-tissue-compartment model is that the calculation of parametric maps is not as straightforward as with the 1-tissuecompartment model. Although it is possible to compute $\mathrm{DV}_{\mathrm{C} 2}$ on a voxel basis, as is demonstrated in Figure 4, one has to fix $\mathrm{DV}_{\mathrm{C} 1}$ to a common value. Without such a measure, voxelwise fits using least-square methods become unstable (20).

An elegant alternative for computing parametric maps is the Logan method as used in this study. Its disadvantage is that only $\mathrm{DV}_{\text {tot }}$-and no measure for specific binding — can

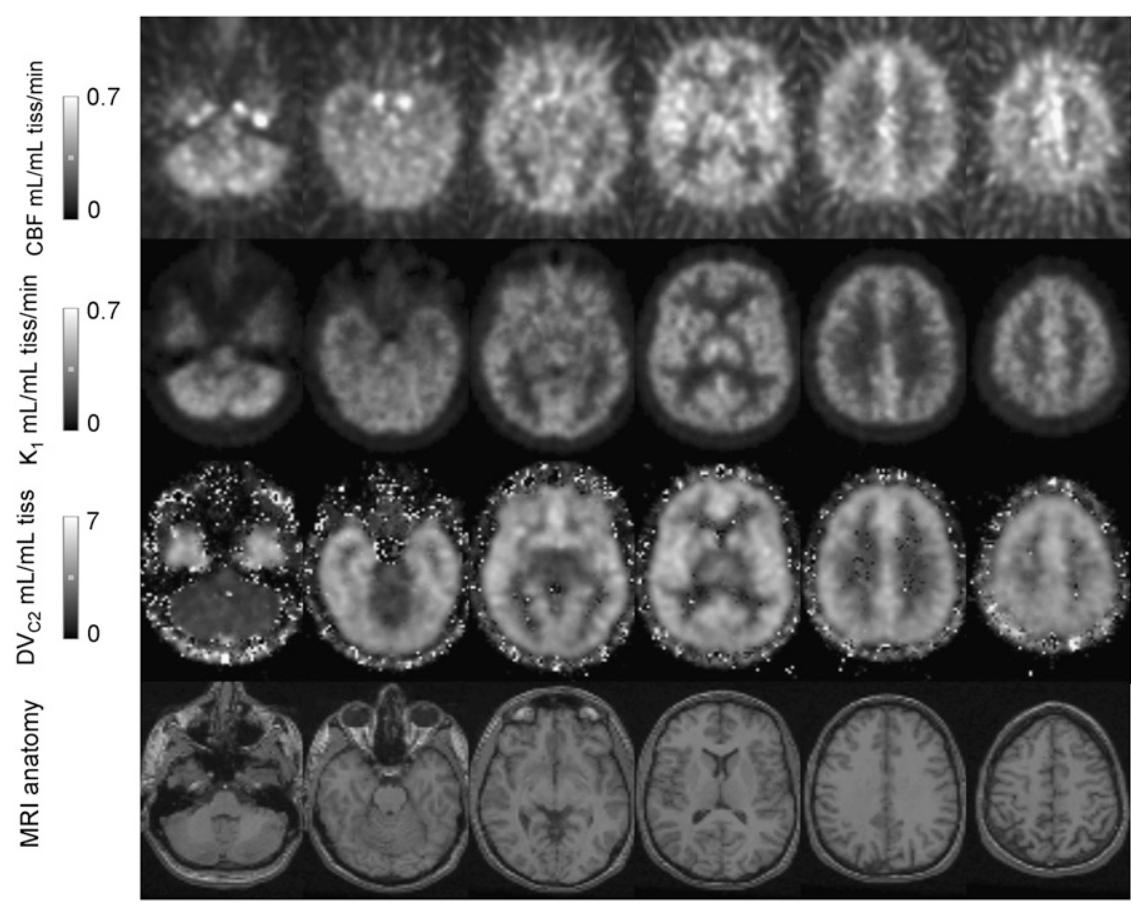

FIGURE 4. Transaxial slices of parametric maps representing $\mathrm{CBF}, \mathrm{K}_{1}, \mathrm{DV}_{\mathrm{C} 2}$, and T1-weighted MR images of volunteer. 


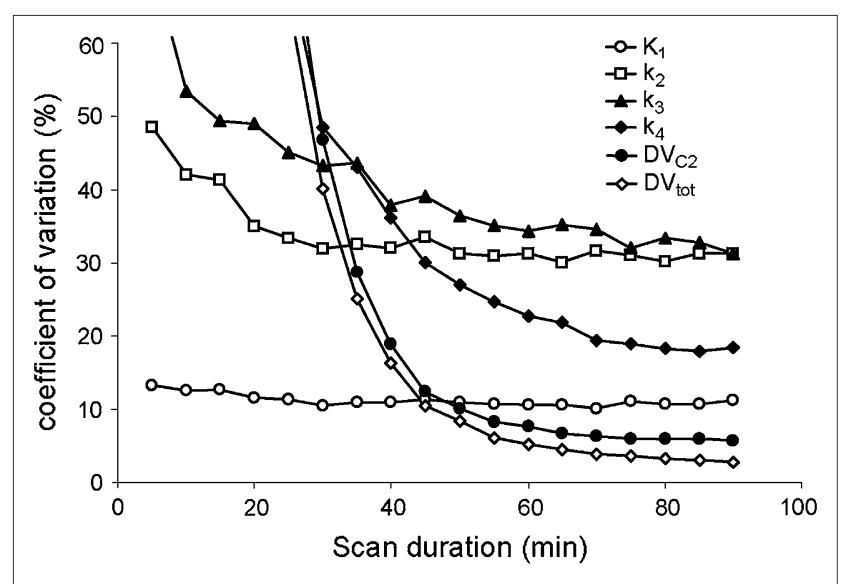

FIGURE 5. Parameter identifiability as function of duration of data acquisition. Data represent result of simulation study in which tissue time-activity curves were generated with 2-tissuecompartment model and $\mathrm{K}_{1}-\mathrm{k}_{4}$ of anterior cingulate (high receptor density). Curves were then refitted after adding gaussian noise. Graph demonstrates COV (\%COV = SD/mean $\times 100$ ) of 1,000 simulations per scan duration.

be calculated. However, there are applications in which the assessment of $\mathrm{DV}_{\text {tot }}$ is sufficient. For example, in blockade studies the change in $\mathrm{DV}_{\text {tot }}$ from a baseline to blockade may yield the needed information. The excellent agreement between $\mathrm{DV}_{\text {tot }}$ calculated with the 2-tissue-compartment model and the Logan method suggests that both methods are equally valid. The slight underestimation of $\mathrm{DV}_{\text {tot }}$ as estimated with the Logan method is most likely due to the presence of statistical noise, as has been described elsewhere (21).

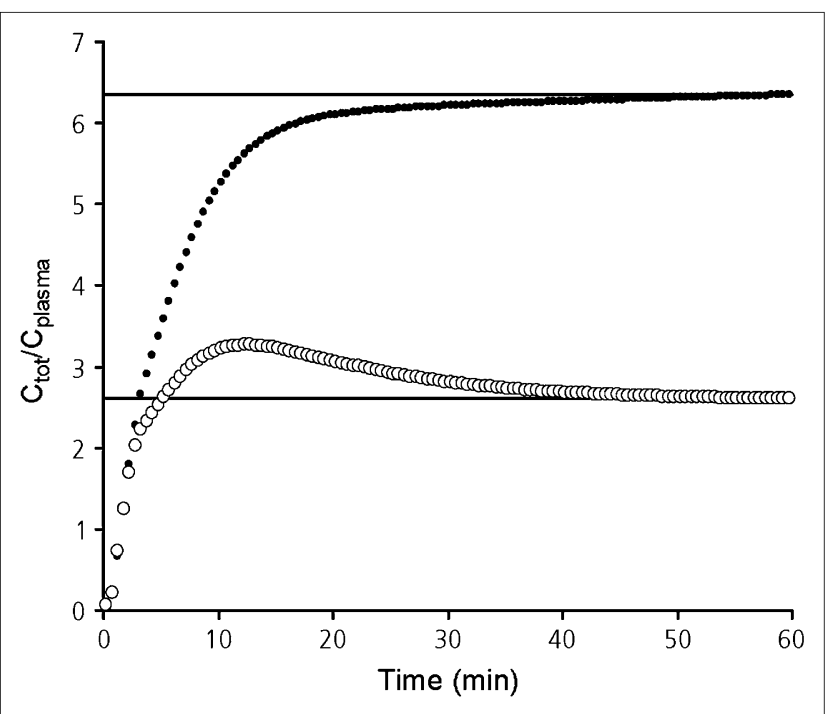

FIGURE 6. Simulated ratio ( ${ }^{11} \mathrm{C}-\mathrm{ABP} 688$ in tissue) $/\left({ }^{11} \mathrm{C}-\right.$ ABP688 in plasma) using "bolus plus constant infusion" protocol. Top curve represents anterior cingulate; bottom curve represents cerebellum. Ratio (bolus/infusion rate) was determined as described in "Materials and Methods."
An important question is whether quantification of mGlu $_{5}$ density might be possible without arterial blood sampling, which is associated with some discomfort for volunteers or patients. Such methods exist if there is a reference region that is devoid of receptors (22-24). Often, the cerebellum or the brain stem is such a region. For ${ }^{11} \mathrm{C}$ ABP688, the situation is not entirely clear yet. However, the fact that $\mathrm{DV}_{\text {tot }}$ values are only slightly more than $50 \%$ lower in the cerebellum than in the anterior cingulate indicates that $\mathrm{mGlu}_{5}$ density in the cerebellum is not negligible. This hypothesis is further supported by the finding that $\mathrm{DV}_{\mathrm{C} 1}$, reflecting nonspecific binding, is only one third of $\mathrm{DV}_{\text {tot }}$ in the cerebellum. If the cerebellum were devoid of $\mathrm{mGlu}_{5}$ receptors, one would expect $\mathrm{DV}_{\text {tot }}$ to equal $\mathrm{DV}_{\mathrm{C} 1}$. However, this study does not prove to what extent $\mathrm{DV}_{\mathrm{C} 1}$ really reflects nonspecific binding, and values derived from tracer kinetic modeling alone have to be interpreted with caution.

In methods $\mathrm{C}$ and $\mathrm{D}$, the distribution of nonspecific binding was assumed to be the same in all regions. This assumption was supported by previous animal studies on mice and rats, which demonstrated a homogeneous ${ }^{11} \mathrm{C}$ ABP688 distribution after blocking of mGlu $_{5}(12,25)$.

\section{CBF, $\mathbf{K}_{\mathbf{1}}, \mathbf{k}_{\mathbf{3}}{ }^{\prime}, \mathbf{k}_{\mathbf{4}}$, and First-Pass EF}

The first-pass EF of $96 \%$ is extremely high and is likely due to the high lipophilicity of the tracer. As a consequence, $\mathrm{K}_{1}$ maps quantitatively reflect $\mathrm{CBF}$, which is illustrated in the left panel of Figure 3. This high EF also leads to high image quality. However, high lipophilicity is often not an advantage for a receptor tracer. If it is coupled with a high $\mathrm{k}_{\text {on }}$ and a low $\mathrm{k}_{\text {off }}$, a high fraction of the delivered tracer would remain bound to the receptors in a blood flow-dependent manner. However, this situation is not the case for ${ }^{11} \mathrm{C}-\mathrm{ABP} 688$. The dissociation constant $\mathrm{k}_{4}$ is large enough to drive the tissue uptake toward an equilibrium state. Nevertheless, full equilibrium between tissue and plasma cannot be achieved with a bolus injection alone. That is why some mathematic algorithm is used to calculate DV or similar receptor density-related parameters. Alternatives to bolus injection are the protocols that add a constant infusion to the bolus. Such "bolus plus constant infusion" protocols have several advantages. They can lead to a fully equilibrated state in which the ratio of tracer in tissue to tracer in plasma is by definition $\mathrm{DV}_{\text {tot }}$. Another advantage is that no arterial input function is needed. Such protocols have been used with various tracers. Recently, Koeppe et al. applied such a protocol to measurement of the vesicular monoamine transporter type 2 with ${ }^{11} \mathrm{C}$-dihydrotetrabenazine (26). If the bolus fraction is large enough, tracer uptake reflects $\mathrm{K}_{1}$ at early time points and tracer accumulation is related to DV at later time points, when the compartments are at equilibrium. The ratio of bolus to infusion rate can be optimized as published by Carson et al. (19). Our analysis yielded an optimal bolusto-infusion rate ratio of 53. As demonstrated in Figure 6, 
equilibrium would then be achieved after $40 \mathrm{~min}$, which would keep the scanning time reasonably short.

\section{CONCLUSION}

${ }^{11} \mathrm{C}$-ABP688 displays favorable kinetics for assessing $\mathrm{mGlu}_{5}$ receptors. For tracer kinetic modeling, 2-tissuecompartment models are clearly superior to models with only 1 tissue compartment. In comparison to the compartmental models, the Logan method is equally useful if only $\mathrm{DV}_{\text {tot }}$ values are required and if fast pixelwise parametric maps are desired. The lack of regions devoid of receptors limits the use of reference region methods that do not require arterial blood sampling. Another advantage of the tracer is the fast kinetics, which allow for relatively short acquisitions.

\section{ACKNOWLEDGMENTS}

This study was financially supported in part by the Swiss National Science Foundation. We thank Milen Blagoev and Cyrill Burger for their support in this study.

\section{REFERENCES}

1. Pin JP, Duvoisin R. The metabotropic glutamate receptors: structure and functions. Neuropharmacology. 1995;34:1-26.

2. Spooren W, Ballard T, Gasparini F, Amalric M, Mutel V, Schreiber R. Insight into the function of Group I and Group II metabotropic glutamate (mGlu) receptors: behavioural characterization and implications for the treatment of CNS disorders. Behav Pharmacol. 2003;14:257-277.

3. Gasparini F, Lingenhohl K, Stoehr N, et al. 2-Methyl-6-(phenylethynyl)-pyridine (MPEP), a potent, selective and systemically active mGlu5 receptor antagonist. Neuropharmacology. 1999;38:1493-1503.

4. Kuhn R, Pagano A, Stoehr N, et al. In vitro and in vivo characterization of MPEP, an allosteric modulator of the metabotropic glutamate receptor subtype 5: review article. Amino Acids. 2002;23:207-211.

5. Spooren W, Gasparini F. mGlu5 receptor antagonists: a novel class of anxiolytics? Drug News Perspect. 2004;17:251-257.

6. Spooren WP, Vassout A, Neijt HC, et al. Anxiolytic-like effects of the prototypical metabotropic glutamate receptor 5 antagonist 2-methyl-6-(phenylethynyl)pyridine in rodents. J Pharmacol Exp Ther. 2000;295:1267-1275.

7. Tatarczynska E, Klodzinska A, Chojnacka-Wojcik E, et al. Potential anxiolyticand antidepressant-like effects of MPEP, a potent, selective and systemically active mGlu5 receptor antagonist. Br J Pharmacol. 2001;132:1423-1430.

8. Gasparini F, Andres H, Flor PJ, et al. $\left[{ }^{3} \mathrm{H}\right]-\mathrm{M}-\mathrm{MPEP}$, a potent, subtype-selective radioligand for the metabotropic glutamate receptor subtype 5. Bioorg Med Chem Lett. 2002;12:407-409.
9. Patel S, Krause SM, Hamill T, Chaudhary A, Burns DH, Gibson RA. In vitro characterization of $\left[{ }^{3} \mathrm{H}\right]$ methoxyPyEP, an mGluR5 selective radioligand. Life Sci. 2003;73:371-379.

10. Hamill TG, Krause S, Ryan C, et al. Synthesis, characterization, and first successful monkey imaging studies of metabotropic glutamate receptor subtype 5 (mGluR5) PET radiotracers. Synapse. 2005;56:205-216.

11. Ametamey SM, Kessler LJ, Honer M, et al. Radiosynthesis and preclinical evaluation of ${ }^{11} \mathrm{C}-\mathrm{ABP} 688$ as a probe for imaging the metabotropic glutamate receptor subtype 5. J Nucl Med. 2006;47:698-705.

12. Ametamey SM, Treyer V, Streffer J, et al. Human PET studies of metabotropic glutamate receptor subtype 5 with ${ }^{11} \mathrm{C}-\mathrm{ABP} 688$. J Nucl Med. 2007;48:247252.

13. Logan J, Fowler JS, Volkow ND, et al. Graphical analysis of reversible radioligand binding from time-activity measurements applied to $\left[\mathrm{N}-{ }^{11} \mathrm{C}\right.$-methyl $]-(-)$-cocaine PET studies in human subjects. J Cereb Blood Flow Metab. 1990;10:740-747.

14. Alpert NM, Eriksson L, Chang JY, et al. Strategy for the measurement of regional cerebral blood flow using short-lived tracers and emission tomography. J Cereb Blood Flow Metab. 1984;4:28-34.

15. Koeppe RA, Holthoff VA, Frey KA, Kilbourn MR, Kuhl DE. Compartmental analysis of $\left[{ }^{11} \mathrm{C}\right]$ flumazenil kinetics for the estimation of ligand transport rate and receptor distribution using positron emission tomography. J Cereb Blood Flow Metab. 1991;11:735-744.

16. Mintun MA, Raichle ME, Kilbourn MR, Wooten GF, Welch MJ. A quantitative model for the in vivo assessment of drug binding sites with positron emission tomography. Ann Neurol. 1984;15:217-227.

17. Buck A, Westera G, vonSchulthess GK, Burger C. Modeling alternatives for cerebral carbon-11-iomazenil kinetics. J Nucl Med. 1996;37:699-705.

18. Akaike H. A new look at the statistical model identification. IEEE Trans Automat Contr. 1974;AC19:716-723.

19. Carson RE, Channing MA, Blasberg RG, et al. Comparison of bolus and infusion methods for receptor quantitation: application to $\left[{ }^{18} \mathrm{~F}\right]$ cyclofoxy and positron emission tomography. J Cereb Blood Flow Metab. 1993;13:24-42.

20. Koeppe RA, Frey KA, Snyder SE, Meyer P, Kilbourn MR, Kuhl DE. Kinetic modeling of $\mathrm{N}-\left[{ }^{11} \mathrm{C}\right]$ methylpiperidin-4-yl propionate: alternatives for analysis of an irreversible positron emission tomography trace for measurement of acetylcholinesterase activity in human brain. J Cereb Blood Flow Metab. 1999; 19:1150-1163.

21. Logan J. Graphical analysis of PET data applied to reversible and irreversible tracers. Nucl Med Biol. 2000;27:661-670.

22. Ichise M, Liow JS, Lu JQ, et al. Linearized reference tissue parametric imaging methods: application to $\left[{ }^{11} \mathrm{C}\right] \mathrm{DASB}$ positron emission tomography studies of the serotonin transporter in human brain. J Cereb Blood Flow Metab. 2003;23:10961112 .

23. Lammertsma AA, Hume SP. Simplified reference tissue model for PET receptor studies. Neuroimage. 1996;4:153-158.

24. Wu Y, Carson RE. Noise reduction in the simplified reference tissue model for neuroreceptor functional imaging. J Cereb Blood Flow Metab. 2002;22:14401452 .

25. Wyss MT, Ametamey SM, Treyer V, et al. Quantitative evaluation of ${ }^{11} \mathrm{C}$-ABP688 as PET ligand for the measurement of the metabotropic glutamate receptor subtype 5 using autoradiographic studies and a beta-scintillator. Neuroimage. 2007;35:1086-1092.

26. Koeppe RA, Gilman S, Joshi A, et al. ${ }^{11} \mathrm{C}$-DTBZ and ${ }^{18} \mathrm{~F}$-FDG PET measures in differentiating dementias. J Nucl Med. 2005;46:936-944. 